\title{
APPLICATION OF CHEN YUANGAO IN THE TREATMENT OF SOFT TISSUE INJURY OF FOOTBALL PLAYERS
}

\author{
APLICAÇÃO DE CHEN YUANGAO NO TRATAMENTO DA LESÃO DOS TECIDOS MOLES DE JOGADORES \\ DEFUTEBOL
}

Original Article

ARTIGO ORIGINAL Artículo Original

\author{
APLICACIÓN DE CHEN YUANGAO PARA TRATAR LESIONES DE TEJIDOS BLANDOSEN JUGADORES \\ DEFÚTBOL
}

\section{Li Mingyu' (D) \\ LiuYu' (1D) \\ Jin Gang ${ }^{2}$ (D) \\ (Basic Medicine)}

1. College of Physical Education and Health, East China Normal University, Shanghai 200241, China. 2. Physical Education Department, Northeastern University, Shenyang, Liaoning, 110000, China.

\section{Correspondence:}

Shenyang, Liaoning, China.

ar63560@21cn.com

\begin{abstract}
The treatment of soft tissue injury in football players generally includes physical therapy, anti-inflammatory and analgesic drug treatment, surgical treatment and early rest immobilization. Western medicine treatment of soft tissue injury can quickly heal the wound and relieve pain in a short time. The treatment of traditional Chinese medicine is based on the whole and must seek the root of the disease. It is believed that the occurrence of certain diseases is related to Qi, blood, liver and kidney deficiency, so we should pay attention to the overall adjustment during treatment of symptoms. In view of this, this study analyzed the effect of Chen Yuan ointment, from traditional Chinese medicine, in the treatment of soft tissue injury. Sixty-eight football players who completed ankle ligament reconstruction were divided into four groups according to the type of operation and whether Chen Yuangao-assisted rehabilitation was used or not. The results showed that the Ankle Hindfoot Function Score and the visual analog scale (VAS) score of patients in the fibula brevis tendon reconstruction Chen Yuan ointment group were 98.3 and 0.3, respectively, at the last follow-up, which were better than those in other groups, and had lower pain scores. This result shows that Chen Yuangao has a certain effect in the treatment of soft tissue injury, which can provide a research idea for the rapid rehabilitation of football players.
\end{abstract}

Keywords: Ointments; Football; Athlete; Soft Tissue Injury.

\section{RESUMO}

O tratamento de lesões dos tecidos moles em jogadores de futebol inclui geralmente terapia física, tratamento anti-inflamatório e analgésico, tratamento cirúrgico e imobilização de repouso precoce. O tratamento de lesões nos tecidos moles, utilizando a medicina ocidental, pode curar rapidamente as lesões e aliviar a dor em pouco tempo. A medicina tradicional chinesa se baseia no todo e deve procurar a raiz da doença. Acredita-se que a ocorrência de certas doenças está relacionada à deficiência de Qi, sangue, fígado e rim do corpo humano, por isso devemos prestar atenção ao ajuste global no tratamento dos sintomas. A partir desta perspectiva, este estudo analisou o efeito da tradicional pomada chinesa Chen Yuan no tratamento de lesões dos tecidos moles. No total, 68 jogadores de futebol que fizeram reconstrução dos ligamentos do tornozelo foram divididos em quatro grupos de acordo com o tipo de operação e se a pomada Chen Yuangao ajudou ou não na reabilitação. Os resultados mostraram que o escore da função do tornozelo retropé (Ankle Hindfoot Function Score) e o escore da Escala Analógica Visual (EVA) dos pacientes do grupo pomada Chenyuan para reconstrução do tendão fibular curto foram 98,3 e 0,3, respectivamente, no último seguimento, sendo melhores do que os de outros grupos e apresentando menores niveis de dor. Estes resultados mostra que a pomada Chen Yuangao exerce certo efeito no tratamento de lesões dos tecidos moles, pode constituir uma ideia de pesquisa para a rápida reabilitação dos jogadores de futebol.

Descritores: Pomadas; Futebol; atleta; Lesões dos Tecidos Moles.

\section{RESUMEN}

El tratamiento de lesiones de los tejidos blandos en jugadores de fútbol incluye generalmente terapia física, tratamiento antinflamatorio y analgésico, tratamiento quirúrgico e inmovilización de reposo precoz. El tratamiento de lesiones en los tejidos blandos, utilizando la medicina occidental, puede curar rápidamente las lesiones y aliviar el dolor en poco tiempo. La medicina tradicional china se basa en el todo y debe procurar la raíz de la enfermedad. Se cree que la ocurrencia de ciertas enfermedades está relacionada a la deficiencia de Qi, sangre, hígado y riñón del cuerpo humano, por eso debemos prestar atención al ajuste global en el tratamiento de los síntomas. A partir de esta perspectiva, este estudio analizó el efecto de la tradicional pomada china Chen Yuan en el tratamiento de lesiones de los tejidos blandos. En total, 68 jugadores de fútbol que hicieron reconstrucción de los ligamentos del tobillo fueron divididos en cuatro grupos de acuerdo con el tipo de operación y si la pomada Chen Yuangao ayudóo no en la rehabilitación. Los resultados mostraron que el escore de la función del retropié del tobillo (Ankle Hindfoot Function Score) y el escore de la Escala Analógica Visual (EVA) de los pacientes del grupo pomada Chenyuan para 
reconstrucción del tendón fibular corto fueron 98,3 y 0,3, respectivamente, en el último segmento, siendo mejores que los de otros grupos y presentando menores niveles de dolor. Estos resultados muestran que la pomada Chen Yuangao ejerce cierto efecto en el tratamiento de lesiones de los tejidos blandos, puede constituir una idea de investigación para la rápida rehabilitación de los jugadores de fútbol.

Descriptores: Pomadas; Fútbol; Atleta; Lesiones de los Tejidos Blandos

\section{INTRODUCTION}

Football is one of the sports events with a high incidence of sports injury. In training and competition, there are often fierce sports physical contact, such as sudden stop, turn, speed change, and even tackle, in which sports injury is easy to occur. ${ }^{1}$ At the same time, due to the wide field, large amount of exercise and fierce confrontation, football not only tests the physical quality of athletes, but also requires high psychological quality. Relevant studies have shown that the main injury site of football is in the lower limbs, and sprain and soft tissue injury are the most prominent types. ${ }^{2}$ In recent years, the incidence of soft tissue injury of football players has an upward trend. The plaster massage therapy represented by Cangwu Taoist Chen Yuan Gao is a characteristic therapy of traditional Chinese medicine. It can reduce pain and alleviate the condition of local muscle fiber swelling, inflammatory cell infiltration and degeneration and necrosis of acute soft tissue injury. Its main components have the effects of detumescence, pain relief, blood enriching and blood activating. ${ }^{3}$ In view of this, this study for football players ankle lateral collateral ligament reconstruction surgery postoperative rehabilitation treatment, using the method of comparative experiment to explore the effect of Chen Yuangao in athletes soft tissue injury recovery.

This paper analyzes the effect of Chenyuan ointment in the treatment of soft tissue injury. Firstly, it elaborates the pharmacology of Chenyuan ointment. The three-dimensional finite element model of human ankle joint was constructed to simulate the reconstruction of $1 / 2$ peroneal brevis tendon and allogeneic tendon. The varus angle at the tibiotalar joint and the normal range of talus movement were determined by front drawer and load test. Methods: 68 football players who received ligament reconstruction surgery were divided into two groups according to the postoperative rehabilitation training process with or without Chen Yuan ointment and the type of operation. The results of the study on the efficacy evaluation of Chen Yuan ointment will have guiding significance for the follow-up treatment of football players who have experienced such injuries.

The innovation of this study is to use 3D model to establish the finite element model of ankle soft tissue injury in different degrees, and simulate the reconstruction of injured lateral collateral ligament with fibula longus tendon and allograft tendon. In the clinical trial, not only the use of Chen Yuan ointment as the contrast variable, but also the use of different reconstruction methods of lateral collateral ligament of the ankle joint as the variable, excluding the impact of surgical factors on postoperative rehabilitation, so that the final effect of the study is more scientific.

\section{RELATED WORKS}

Football is a kind of high-intensity antagonistic sport. Due to muscle fatigue, insufficient preparation or technical problems, it is easy for athletes to have soft tissue injury such as ankle closing waist. People pay more and more attention to sports safety, and there are more and more researches on sports injury and soft tissue injury. Zhou HQ's team performed open reduction and internal fixation via posterolateral approach in 25 patients with Pilon fracture complicated with soft tissue injury, so as to evaluate the clinical efficacy of plate lag screw internal fixation via posterolateral approach in the treatment of Pilon fracture with soft tissue injury. Finally, it is considered that this method can avoid the damage to the anteromedial skin and soft tissue without causing further damage. ${ }^{4}$ ROSENDAHL K and other scholars reviewed the sports injuries of children's musculoskeletal system, including the description of sports related injuries in children and adolescents, and briefly mentioned the injuries after bone and joint fusion. ${ }^{5}$ Kerr ZY's team discussed the design and analysis of systems that affect the interpretation and understanding of exercise-related concussion data by the sports injury monitoring system. The study will contribute to the development of sports injury monitoring systems and research to identify risk factors, develop prevention strategies, and evaluate prevention mechanisms. ${ }^{6}$ Everhart J S and other scholars used 34 psychological factor assessment scales to study 152 sports injury treatment results, in order to analyze the application effect of psychological assessment tools in sports injury treatment effect evaluation.? Based on the fact that pressure injury is a symptom of widespread system failure and poor care, gamston J and other scholars introduced in detail the best practice of evaluating and preventing these injuries in the emergency department. This research will be of great significance to the treatment of stress soft tissue injury. ${ }^{8}$ According to the time of risk exposure in youth team sports, Soomro n's team determined the overall efficacy of structured multi-level IPPs integrating warm-up and neuromuscular strength, and conducted a systematic review and meta-analysis of the literature in multiple databases. The results showed that in 10 studies including 9 RCTs, the IRR of the composite population point estimate was $0.60 .^{9}$

The above research results show that scholars focus on the causes of soft tissue injury, the efficacy and mechanism of some specific drugs. However, there are few researches on the treatment of soft tissue injury and football players injury characteristics. In view of this, this study aimed at the common ankle ligament damage of football players, and analyzed the efficacy of traditional Chinese medicine Cangwu Taoist Chen Yuan ointment, in order to provide a certain reference value for the treatment of football players' soft tissue injury.

\section{SOFT TISSUE INJURY MODEL OF FOOTBALL PLAYERS Experimental design of Chen Yuan ointment in the treat-
ment of ankle joint injury}

In this study, a number of patients with ankle soft tissue injury and received surgery were tested to explore the effect of Chen Yuangao in the treatment of ankle soft tissue injury. A total of 68 football players with old injury of lateral collateral ligament of ankle joint underwent 1 / 2 peroneal brevis tendon and allogeneic tendon respectively. After different tendon reconstruction operations, the patients in each group received normal rehabilitation training and Chen Yuangao assisted rehabilitation. All patients in this study signed informed consent.

Table 1 shows the basic information of the participants in this study. In group A, there were 17 patients with 1 / 2 fibula brevis tendon normal rehabilitation, with 9 and 8 athletes in male and female; in group $B, 1$ / 2 fibular brevis tendon Chen Yuan ointment assisted rehabilitation, with 17 patients, 7 males and 10 females; group C, allogeneic tendon 
Table 1. Basic information of patients participating in the trial.

\begin{tabular}{c|c|c|c|c|c}
\hline Group & Gender & average age & group & Gender & average age \\
\hline \multirow{2}{*}{$\mathrm{A}$} & Male & $32.2 \pm 2.5$ & \multirow{2}{*}{$\mathrm{N}$} & Male & $32.1 \pm 2.0$ \\
\cline { 2 - 3 } \cline { 5 - 6 } & female sex & $32.4 \pm 1.8$ & & female sex & $32.1 \pm 1.5$ \\
\hline \multirow{2}{*}{$\mathrm{B}$} & Male & $32.4 \pm 3.0$ & \multirow{2}{*}{$\mathrm{N}$} & Male & $32.5 \pm 1.0$ \\
\cline { 2 - 3 } \cline { 5 - 6 } & female sex & $31.9 \pm 1.6$ & & female sex & $32.0 \pm 0.8$ \\
\hline
\end{tabular}

normal rehabilitation, with 16 patients, 8 males and 8 females; group $D$, allogeneic tendon Chen Yuan ointment assisted rehabilitation There were 18 patients, 10 males and 8 females. There was no significant difference in gender, age, degree of injury, operation condition and routine rehabilitation measures in each group $(P>0.05)$.

The main outcome measures were operation time, hospital stay, wound complications and fever (the patient's temperature was more than $37.2^{\circ}$ ). After the operation, the patients were followed up every other week. After two months, the frequency of follow-up was reduced to once a month. During each follow-up, the frequency and duration of postoperative rehabilitation training and whether they were in accordance with the specifications were monitored. At each follow-up, the ankle hindfoot function was scored, and the degree of recovery was directly proportional to the score; according to the standard of visual analog score, the higher the score, the higher the degree of pain; the talus anteversion angle and talus forward distance of patients were recorded to evaluate the stability and recovery of ankle joint.

\section{Effect analysis of Chen Yuan ointment in the treatment of soft tissue injury of football players}

In this study, 68 football players were involved in the experiment. During the follow-up period, one case of group C patients had wound infection, and the infection disappeared after local drug exchange. All patients had adverse reactions related to the graft material. There were significant statistical differences between the four groups of fever time, operation time and hospitalization time, and the specific results are shown in Figure 1.

The comparison of operation time, fever time and hospitalization time under different ligament reconstruction methods is shown in Figure 1. The average operation time of peroneal brevis tendon reconstruction was 87.7 minutes, the postoperative fever was about 2.7 days, and the postoperative hospitalization observation was 10.3 days; the average time of allogeneic tendon reconstruction was 61.1 minutes, the postoperative fever was about 5.3 days, and the postoperative hospitalization observation was 12.2 days. There was significant statistical difference between the two methods $(P<0.05)$.

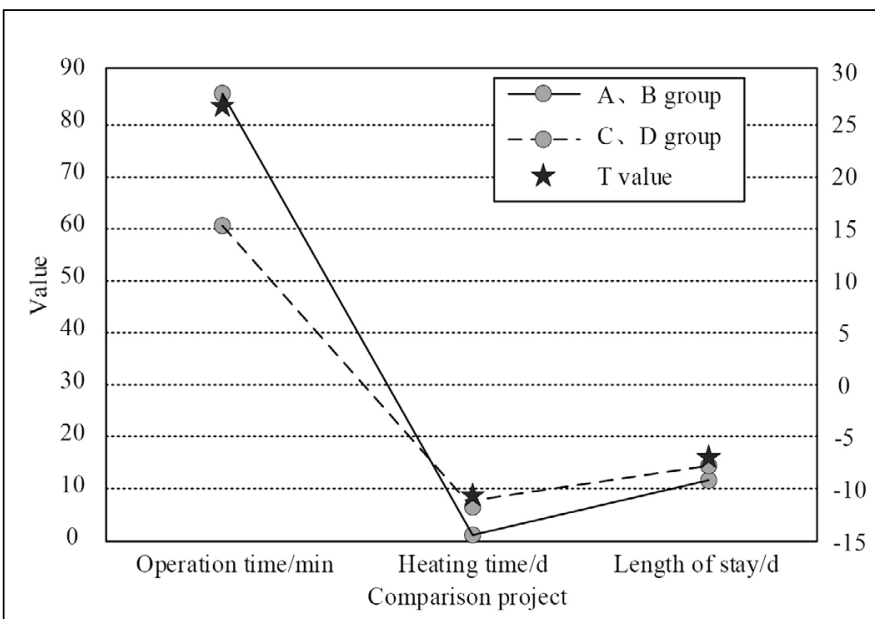

Figure 1. Comparison of basic conditions of different ankle ligament reconstruction methods.
The ankle hindfoot function scores of all the athletes participating in the trial before and during the recovery period after the operation are shown in Figure 2. The AOFAS scores of the patients who underwent fibula brevis tendon reconstruction were slightly higher than those of the allogeneic tendon group, that is, the initial score of group A and group B was higher than that of group $C$ and Group D. During the rehabilitation period of athletes after operation, the AOFAS score of the patients who used Chen Yuan plaster assisted rehabilitation was higher than that of the patients without Chen Yuan ointment, which proved that Chen Yuan ointment had a good therapeutic effect on the injury of lateral collateral ligament of ankle joint. In the last follow-up, the AOFAS score of group B was 98.3, which was significantly higher than that of other groups. The above results show that the functional injury of ankle joint in patients with peroneal brevis tendon surgery is lighter, and can almost recover to a higher level after postoperative rehabilitation. The use of Chen Yuan ointment to assist rehabilitation training can promote the rehabilitation of patients after operation.

Figure 3 shows the VAS score before and after operation. There was no significant difference in VAS score of all patients with peroneal brevis tendon reconstruction before surgery than those who underwent allogeneic tendon reconstruction ( $P=0.267)$. In the late follow-up, the VAS score of patients with Chen Yuan ointment assisted rehabilitation therapy was significantly lower than that of patients receiving the same type of surgery, but the postoperative rehabilitation treatment of patients without Chen Yuan ointment auxiliary treatment was significantly lower. In the last follow-up, the average VAS score of group B was 0.3 , and there was a significant statistical difference between the two groups $(P<0.05)$. The above experimental data show that $C h e n$ Yuan ointment

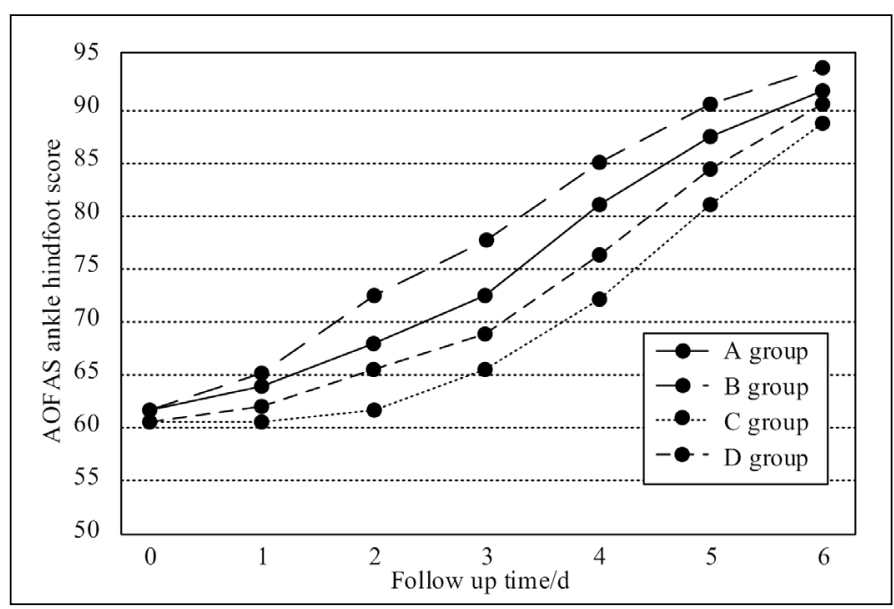

Figure 2. AOFAS ankle hindfoot function score before and after operation.

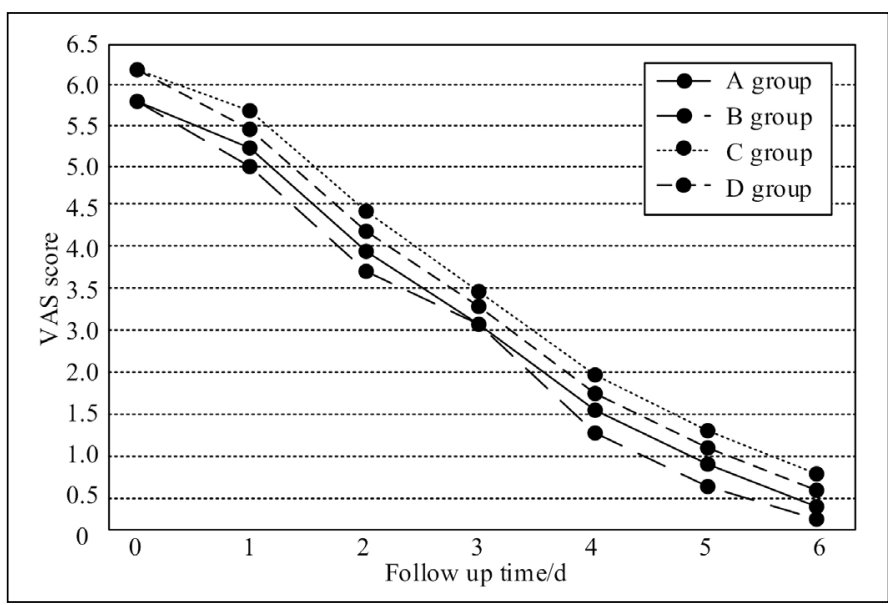

Figure 3. VAS score before and after operation. 
can effectively reduce the pain degree of patients after ankle ligament reconstruction, and the drug has analgesic effect.

The anteversion of talus and the distance of talus anteversion before operation and at the last follow-up are shown in Figure 4. After surgery and rehabilitation training, the anteversion angle of talus and the distance of talus anteversion returned to normal level, indicating that the operation and rehabilitation of patients were good. The recovery of patients treated with Chenyuan ointment was better than those without. The $P$ values of preoperative talus anteversion, last follow-up talus anteversion, preoperative talus anteversion distance and last follow-up talus anteversion distance were $0.461,0.049,0.247$ and 0.323 , respectively. There was no significant difference between different groups of patients

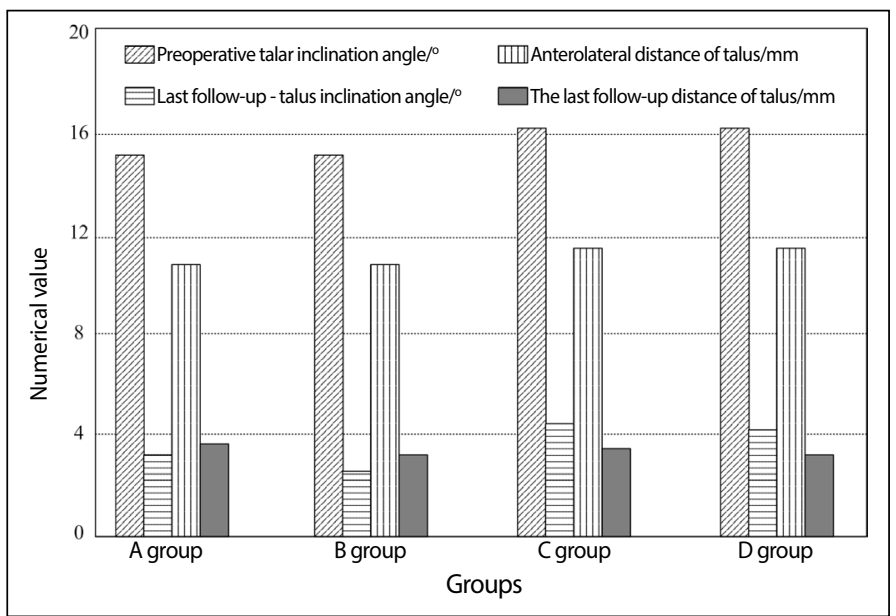

Figure 4. Comparison of talus inclination angle and talus forward distance before and after operation. before operation. At the last follow-up, there was no significant statistical difference in the talus anteversion distance, but in the talus anteversion angle The difference was statistically significant.

\section{CONCLUSION}

Chen Yuan Gao was created by Cangwu Taoist priest and formed by countless people's experiments, innovations and improvements. It has a good effect in the treatment of human bone and joint diseases. It can treat all rheumatism, bone pain and arthralgia. With the promotion of China's international status, the application scope of traditional Chinese medicine has gradually expanded. Based on the understanding of the pharmacology of Chenyuan ointment and the structure of human ankle joint, the effect of Chenyuan ointment on soft tissue injury was analyzed, and a 3D finite element analysis model of human ankle joint was constructed. According to the type of ankle ligament reconstruction and whether Chen Yuan ointment was used in the rehabilitation training, 68 athletes were divided into four groups. The AOFAS score, VAS score, talus anteversion and talus anteversion distance were recorded. Comparative analysis showed that the pain degree of $1 / 2$ fibula brevis tendon reconstruction and allograft tendon reconstruction was different. At the last follow-up, the talus inclination angle of the peroneal brevis tendon Chen Yuan ointment group was $3.1^{\circ}$ and the talus forward distance was $3.6 \mathrm{~mm}$, which basically returned to the normal level. This shows that Chen Yuan ointment has a good effect in the treatment of soft tissue injury. After that, it is necessary to further study the usage and dosage of Chen Yuan ointment in the treatment of different soft tissue injuries.

The author declare no potential conflict of interest related to this article

AUTHORS' CONTRIBUTIONS: The author has completed the writing of the article or critical comments on its knowledge. This paper can be used as the final manuscript. Every author has made an important contribution to this manuscript. Li Mingyu is responsible for the design of the experiment, Yu Liu is responsible for the data analysis and the writing and implementation of the experiment, and Jin Gang is responsible for the translation and proofreading.

\section{REFERENCES}

1. Song Y, Ma SQ, Bi YN, et al. Identification of Sphingomonas paucimobolis from a case of soft tissue injury, based on the phenotypic characteristics and 165 rRNA gene sequence. Reviews in Medical Microbiology. 2015; 26(2):70-73.

2. Ibrahim DA, Swenson A, Sassoon A, et al. Classifications In Brief: The Tscherne Classification of Soft Tissue Injury. Clinical Orthopaedics \& Related Research. 2017; 475(2):1-5.

3. Nung RCH, Lee RKL, Ng AWH. Ultrasonographic findings of suspected retained foreign body in soft tissue following penetrating injury. Hong Kong Journal of Radiology. 2017; 20(1):76-83.

4. Zhou HQ, Chen JY, Deng W, Nie CW, Hu GB, Ren X. Treatment of Pilon fractures complicated with soft tissue injury by plate and lag screw fixation via posterolateral approach. Zhongguo Gu Shang. 2018;31 (8):775-778.

5. Rosendahl K, Strouse PJ. Sports injury of the pediatric musculoskeletal system. La radiologia medica. 2016; 121(5):431-441.
6. Kerr ZY, Zuckerman SL, Register-Mihalik JK, Wasserman EB, Valovich McLeod TC, Dompier TP, et al. Estimating Concussion Incidence Using Sports Injury Surveillance Systems: Complexities and Potential Pitfalls. Neurol Clin. 2017;35(3):409-434.

7. Everhart JS, Harris K, Chafitz A, Kirven JC, Abouljoud M, Schiele S, et al. Psychological Assessment Tools Utilized in Sports Injury Treatment Outcomes Research: A Review. J Sports Sci Med. 2020 May 1;19(2):408-419.

8. Gamston J. Pressure induced skin and soft tissue injury in the emergency department. Emerg Med J. 2019;36(10):631-634.

9. Soomro N, Sanders R, Hackett D, Hubka T, Ebrahimi S, Freeston J, et al. The Efficacy of Injury Prevention Programs in Adolescent Team Sports: A Meta-analysis. Am J Sports Med. 2016 Sep;44(9):2415-24. 